\title{
MIP-like substance in the brain of Perinereis nuntia Savigny, 1818 (Polychaeta, Annelida) detected by immunocytochemistry
}

\author{
Wan-Xi Yang ${ }^{1^{*} \dagger}$, Hans-Uwe Dahms ${ }^{2^{*}}$, Iskandar Mirabdullayev ${ }^{2}$ \\ ${ }^{1}$ The Sperm Laboratory, Institute of Cell Biology and Genetics, College of Life Sciences, Zhejiang \\ University, Hangzhou 310058, China. \\ ${ }^{2}$ Green Life Science Department, Sangmyung University, Seoul 110-743 South Korea. \\ ${ }^{3}$ Institute of Zoology, Tashkent 700095, Uzbekistan. \\ † Corresponding author e-mail: wxyang@spermlab.org
}

\begin{abstract}
Molluscan insulin-like peptides (MIPs) were first identified from the cerebral ganglion of a freshwater pulmonate, the snail Lymnaea stagnalis. Recently, MIPs received considerable attention due to their molecular similarity to insulins of higher taxa including humans. It has been suggested that MIPs play an important role in the growth and cell differentiation of peripheral organs of mollusks. The striking similarity between the embryology of mollusks and polychaetes has long been recognized and supports the view that polychaetes and mollusks are evolutionarily related. In this study, we used polyclonal antibodies against the MIP1C-chain of L. stagnalis to detect the MIP immunoreactive cells in the brain of the locally common polychaete Perinereis nuntia. MIP immunoreactive cells were detected in the $P$. nuntia brain by confocal and epifluorescent microscopy. These cells were located in the periphery and posterior regions of the brain but not in the anterior region. The cells varied from 10 to $20 \mu \mathrm{m}$ in diameter. Electron microscopic studies of ultra-thin sections of the $P$. nuntia brain, labeled by an immuno-gold secondary antibody, confirmed the presence of MIP-immunoreactive neurons in the brain. MIP-immunoreactive secretory granules were found in axon terminals, which co-existed with synaptic vesicles in the neuropile of the brain. The potential functions of MIP-like substances in polychaetes are discussed.
\end{abstract}

KEY WORDS: immunocytochemistry, molluscan insulin-like peptides, MIP immunoreactive cells, neurotransmitters.

\section{MIP-подобная субстанция в мозге Perinereis nuntia Savigny, 1818 (Polychaeta, Annelida) определена иммуноцитохимически}

\author{
Ван-Кси Янг', Г.-У. Дамс², И. Мирабдуллаев ${ }^{3}$ \\ ${ }^{1}$ The Sperm Laboratory, Institute of Cell Biology and Genetics, College of Life Sciences, Zhejiang \\ University, Hangzhou 310058, China. \\ ${ }^{2}$ Green Life Science Department, Sangmyung University, Seoul 110-743 South Korea. \\ ${ }^{3}$ Институт зоологии, Ташкент 700095, Узбекистан.
}

РЕЗЮМЕ: Инсулино-подобные пептиды моллюсков (МІР) были впервые обнаружены в церебральных ганглиях пресноводного легочного моллюска - прудовика

* Authors contributed equally to this work. The authors declare no conflict of interest. 
Lymnaea stagnalis. В последнее время на MIP обращено значительное внимание изза их молекулярного сходства с инсулином высших животных таксонов включая человека. Предполагается, что МІР играют важную роль в росте и клеточной дифференциации периферических органов моллюсков. Большое сходство в эмбриологии моллюсков и полихет отмечено давно и подтверждает их эволюционную близость. В данном исследовании мы использовали поликлональные антитела против MIP1C-цепочки L. stagnalis для обнаружения MIP-чувствительных клеток мозга Perinereis nuntia. MIP-чувствительные клетки были обнаружены в мозге P. nuntia с помощью конфокальной и эпифлуоресцентной микроскопии. Эти клетки располагаются в периферической и задней областях мозга, но отсутствуют в его передней области. Диаметр клеток варьирует от 10 до 20 мкм. Электронномикроскопическое исследование ультратонких срезов мозга $P$. nuntia меченых золото-иммунных вторичных антител подтвердило наличие МІР-чувствительных нейронов в мозге. МIPчувствительные секреторные гранулы были обнаружены в окончаниях аксонов рядом с синаптическими везикулами в нейропиле мозга. Обсуждаются возможные функции МІР-подобных веществ в полихетах.

КЛЮЧЕВЫЕ СЛОВА: иммуноцитохимия, инсулино-подобные пептиды моллюсков, МІР-чувствительные клетки, нейротрансмиттеры.

\section{Introduction}

Substances used as neurotransmitters belong to three distinct families: amines, purines and peptides. Often called classical or small molecule transmitters, the members of the amine family include acetylcholine, amino acids and other substances derived from common amino acids that are synthesized through a few enzymatic steps. All of these transmitters are produced in the cytosol of nerve endings and then taken up into vesicles for release when the neuron is stimulated (Froesch et al., 1985).

The family of neuropeptides includes opioids, neurohypophyseal tachykinins, secretins, pancreatic polypeptide related gastrins, and insulins (Schwartz, 2001). Insulin itself is involved in the regulation of normal glucose homeostasis, as well as in other specific physiological functions. It is synthesized as a propeptide from which an endoplasmatic reticulumtargeting sequence is cleaved to yield proinsulin. Proinsulin contains the regions $A$ and $B$ and is separated by an intervening connecting region, $\mathrm{C}$. The connecting region is cleaved, liberating an active protein, which contains the $\mathrm{A}$ and $\mathrm{B}$ chains, and held together by 2 disulphide bonds (Girbau et al., 1987). Molluscan insulinrelated peptides 1 to 5 (MIP) are evolutionarily related to insulin; relaxin; insulin-like growth factors I and II; mammalian Leydig cell-specific insulin-like peptides (ELIP) (gene INSL4); insect prothoracicotropic hormones (bombyxin); locust insulin-related peptides (LIRP); and insulin-like peptides. Structurally, all these peptides consist of two polypeptide chains (A and B) linked by two disulphide bonds. They all share a conserved arrangement of four cysteines in their A chain. The first of these cysteines is linked by a disulphide bond to the third one and the second and fourth cysteines are linked by interchain disulphide bonds to cysteines in the B chain (Smit et al., 1991).

The molluscan insulin-related peptide(MIP) was first identified and sequenced from light green cells in the cerebral ganglion of the freshwater snail, Lymnaea stagnalis (Smit et al., 1988; Li et al., 1992). Since then, considerable attention has been given to MIPs because of their structural similarities to mammalian insulin. After the first MIP and its gene were sequenced, MIP II, III, and V have been identified (Smit et al., 1991; Smit et al., 1993, 1998; Li, Geraerts, 1992). At the same time, MIP-immu- 
noreactivities were detected in other molluscs (Sonetti et al., 1992; Chang et al., 2000). A physiological function of MIPs as growth hormones was hypothesized. Besides bombyxins from the lepidopteran Bombyx mori (Kawakami et al., 1989) and a locust insulin-related peptide (LIRP) from Locusta migratoria and other insects (Laqueux et al., 1990), MIPs are the third member of the insulin superfamily which have been structurally identified in invertebrates ( $\mathrm{Ru}$ sakov et al., 2003). Insulin-like peptides occur in geologically old invertebrate lineages and are suggested to have evolved to mammalian insulins and insulin-like growth factors (IGFs).

Some molluscan neuropeptides, e.g. the sodium influx stimulating peptide (SISP) and FMRFamide from several molluscan species, were detected in the nereid nervous system as well (Krajniak, Price, 1990; Guissi-Kadri et al., 1991; Dugimout et al., 1992; Krajniak, Greenberg, 1992). Insulin immunoreactive neurofibers were detected in the peduncles of the corpora pedunculata of Nereis virens, but no immunoreactive perikaryas were found (Porchet, Dhainaut-Courtois, 1988). Polychaetes are among the geologically oldest invertebrate taxon where insulin-immunoreactivities have been reported (Porchet, Dhainaut-Courtois, 1988). The aim of this work is to investigate the presence of a molluscan insulin-related peptide in Perinereis nuntia Savigny 1818, and to discuss the possible function of this peptide in polychaetes. This is achieved using confocal laser scanning microscopy on whole mount nereid brains; epifluorescent microscopy on paraffin sections and immunotransmission electron microscopy on ultra-thin sections.

The most remarkable feature of the cerebral ganglion in several families of errant polychaetes (also in the sedentary Serpulidae) according to Golding (1992) is the presence of corpora pedunculata, i.e., stalked bodies, resembling those of arthropods. They are composed of myriads of tiny neuronal somata, globuli cells, aggregated into compact bodies that contain little glia and whose stalks are composed of bundles of aligned axons. The number present varies with species. Nephtys species have dis- tinct clusters of globuli cells, but these lack stalks (Clark, 1958). Similarly, compact bodies of small primary or secondary sensory cells may be formed in other regions of the brain and send fibers to specialized areas of the glomerular neuropil.

\section{Materials and Methods}

\section{Experimental invertebrates and chem-} icals

Perinereis nuntia (Polychaeta, Nereidae) was collected off the coast of Qingdao $\left(36^{\circ} 04^{\prime} \mathrm{N}\right.$, $120^{\circ} 22^{\prime} \mathrm{E}$ ), China and maintained in aquaria, where the seawater in the aquarium was aerated, recycled with a submerged water pump and replenished every week. Seawater was maintained at room temperature $\left(25^{\circ} \mathrm{C}\right)$. Only those individuals that had not metamorphosed to heteronereids were used for experimentation.

A polyclonal antibody against the $\mathrm{C}$-chain of MIP1 was obtained from Professor A.B. Smit (Vrije University Netherlands, Amsterdam). A rhodamine conjugated secondary antibody against rabbit IgG was purchased from Calbiochem-Novabiochem Corporation. Other immunocytochemicals and reagents were obtained from Sigma Chemical Company. Details about the purification, epitope, immunogen and previous characterization of the antibody are referenced by this company.

Immunocytochemical detection in paraffin sections

Brains of $P$. nuntia were dissected and fixed in $4 \%$ formaldehyde in phosphate buffered saline PBS for $4 \mathrm{~h}(\mathrm{pH}=7.4)$. Brains were then dehydrated in serial dilutions of ethanol $(30 \%$, $50 \%, 70 \%, 80 \%, 90 \%, 100 \%$ for 10 minutes at each dilution) and embedded in paraffin. Paraffin sections of $6 \mu \mathrm{m}$ were attached to poly-lysine coated coverslips, and then deparaffined and rehydrated. Subsequently, the sections were incubated in $20 \mathrm{mM}$ sodium borohydride in PBS for $10 \mathrm{~min}$ and blocked with $5 \%$ bovine serum albumin (BSA) in PBS for $30 \mathrm{~min}$. Normal rabbit serum was used instead of the primary 
antibody as a negative control. After blocking, the sections were incubated in diluted 1:250 MIP polyclonal antibody for $45 \mathrm{~min}$ at $37^{\circ} \mathrm{C}$. After rinsing in PBS, the sections were incubated in 1:100 secondary antibody against rabbit IgG conjugated with rhodamine at $37^{\circ} \mathrm{C}$ for 45 min. Sections were rinsed in PBS and mounted in $1: 1$ glycerol/PBS before observation by epifluorescence microscopy.

\section{Confocal microscopy on whole mounted brains}

Prefixed brains of Perinereis nuntia were rinsed in PBS, and then subjected to a series of ethanol dilutions for $10 \mathrm{~min}$ (as above). In 100\% ethanol, $3 \%$ hydrogen peroxide was added to reduce nonspecific staining. Brains were incubated in $1 \mathrm{mg} / \mathrm{ml}$ collagenase in PBS (5 min). Each brain was manually desheathed with fine forceps under the dissecting microscope. Brains were then rinsed in $0.1 \%$ triton $\mathrm{x}-100$ in PBS (PBS-x) and preblocked in 5\% BSA in PBS- $x$ for $3 \mathrm{~h}$. After blocking, brains were incubated in diluted 1:250 primary antibody against MIP in PBS-x overnight at $4^{\circ} \mathrm{C}$. Normal rabbit serum was used as a negative control. After being rinsed in PBS-x for $12 \mathrm{~h}$ at $4^{\circ} \mathrm{C}$ with at least 5 changes, each brain was incubated overnight at $4^{\circ} \mathrm{C}$ in diluted secondary antibody (1:100 in PBS-x), similar to the paraffin section immunostaining experiment. After being rinsed in PBS-x, brains were mounted in a depression slide in 1:1 glycerol/PBS and observed under the confocal laser scanning microscope (Biorad MRC-600).

\section{Immunocytochemistry on ultrathin sections}

Perinereis nuntia brains were fixed in $1 \%$ glutaraldehyde which was diluted in $50 \mathrm{mM}$ sodium cacodylate buffer ( $\mathrm{pH}$ 7.4) for $1 \mathrm{~h}$ on ice, and postfixed in $1 \%$ osmium tetroxide in the same buffer for $1 \mathrm{~h}$. After rinsing, brains were dehydrated in ethanol and embedded in epoxy resin. Ultra thin sections of $60 \mathrm{~nm}$ were mounted on uncoated nickel grids. The sections were etched in $1 \%$ sodium metaperiodate for $10 \mathrm{~min}$ at room temperature, then rinsed in distilled water, preblocked in PBS containing $0.1 \%$ BSA and $50 \mathrm{mM}$ lysine for $15 \mathrm{~min}$. Subsequently, they were incubated in 1:80 MIP antibody in $0.1 \% \mathrm{BSA} / \mathrm{PBS}$ overnight at $4^{\circ} \mathrm{C}$. Then, the sections were rinsed in PBS containing $0.1 \%$ BSA for 20 min and incubated for $1 \mathrm{~h}$ in 1:50 goat anti-rabbit IgG antibody conjugated with 5 $\mathrm{nm}$ gold particles at room temperature. The sections were rinsed in $0.1 \% \mathrm{BSA} / \mathrm{PBS}$ and stained with uranyl acetate for 20 min before being examined under a Philips CM 120 transmission electron microscope (TEM). For normal ultrastructural observations the sections were stained with uranyl acetate for $20 \mathrm{~min}$ before being examined by TEM.

Fig. 1. A - whole mount of a Perinereis nuntia brain stained with $3 \mu \mathrm{g} / \mathrm{ml}$ DAPI. The brightest parts at the lateralanterior regions of the brain are corpora pedunculata $(\mathrm{CP})(\mathrm{scale}=100 \mu \mathrm{g}) ; \mathrm{B}-$ semi-thin sections stained with $3 \mu \mathrm{g} /$ $\mathrm{ml}$ DAPI show the regularly folded shape of the $\mathrm{CP}($ scale $=40 \mu \mathrm{m}) ; \mathrm{C}$ - semi-thin sections stained with $3 \mu \mathrm{g} / \mathrm{ml}$ DAPI showing the nuclei of the CP cells and that of other neurons (scale $=4 \mu \mathrm{m}$ ); D - TEM micrograph of the CP cells containing little cytoplasm and many mitochondria: $\mathrm{n}$ - nucleus, arrow pointed towards mitochondria $(\mathrm{scale}=5 \mu \mathrm{m})$; E - TEM micrograph of corpora pedunculata cells and nerve fibers outside the CP $($ scale $=2 \mu \mathrm{m}) ; \mathrm{F}-\mathrm{TEM}$ micrograph of a neuron at the posterior region of the brain with a large amount of cytoplasm and numerous granules: $\mathrm{n}=$ nucleus, arrow pointing at granules (scale $=0.5 \mu \mathrm{m}$ ). These experiments were performed for three times - the images are derived from 5 brains.

Рис. 1. А - целый препарат мозга Perinereis nuntia окрашенный DAPI (3 мкг/мл). Самые светлые части переднебоковых областей - corpora pedunculata (CP) (масштаб 100 мкм); В - полутонкие срезы окрашенные DAPI (3 мкг/мл) выявляют равномерно изогнутую форму СР (масштаб 40 мкм); С — полутонкие срезы окрашенные DAPI (3 мкг/мл) выявляют ядра клеток СР и других нейронов (масштаб 4 мкм); D — трансмиссионная электронная микрофотография клеток СР содержащих немного цитоплазмы и много митохондрий: $\mathrm{n}$ - ядро, стрелки указывают митохондрии (масштаб 2 мкм); Е - трансмиссионная электронная микрофотография клеток СР и нервных волокон снаружи от СР (масштаб 2 мкм); F — трансмиссионная электронная микрофотография нейрона в задней части мозга с большим количеством цитоплазмы и множеством гранул (масштаб 0,5 мкм). Эксперименты были проведены три раза - изображения получены от 5 экземпляров. 

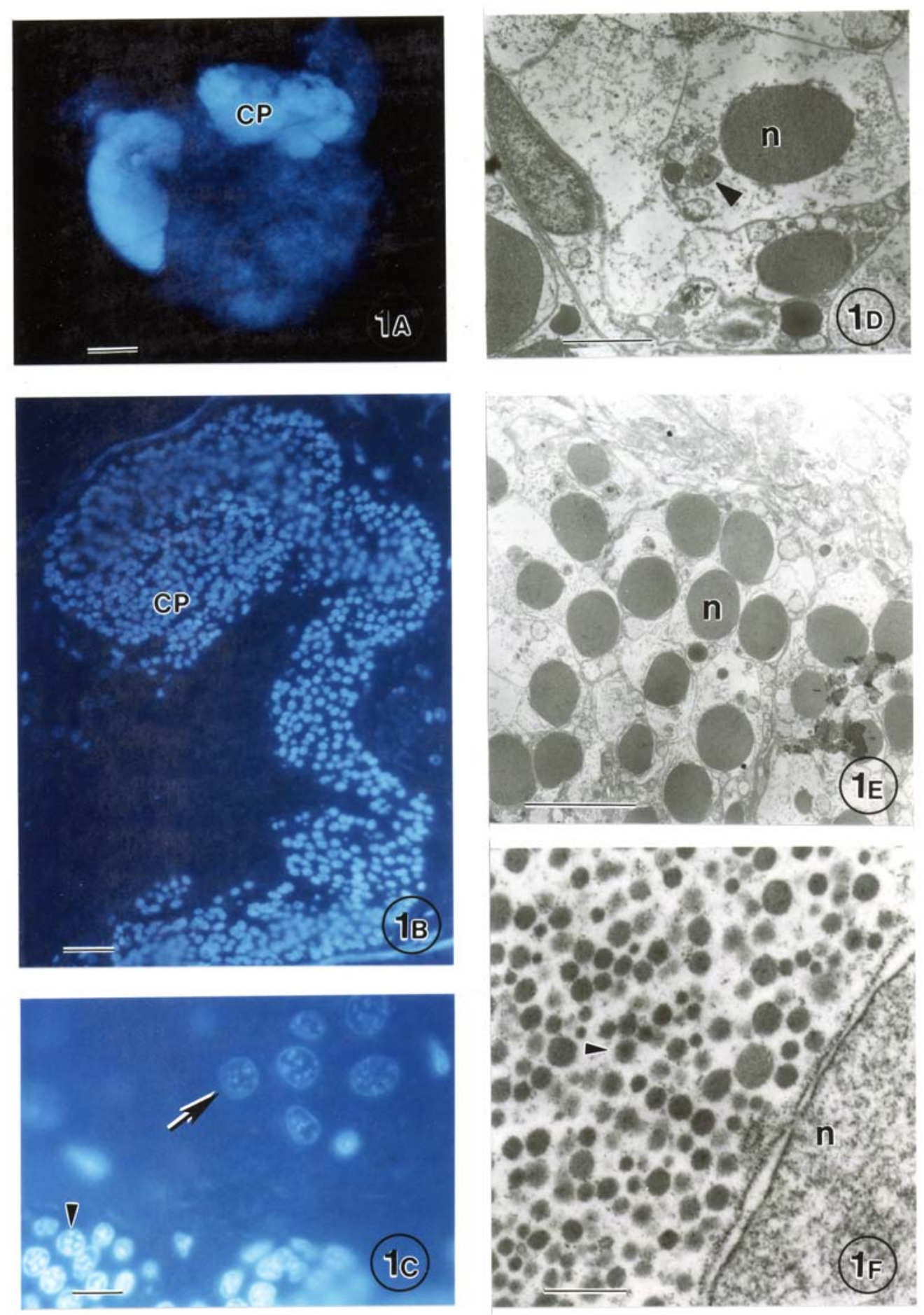
DAPI staining

In order to show nerve cell nuclei, whole mounts of the brain (Fig. 1) and $1 \mu \mathrm{m}$ semithin epoxy sections of Perinereis nuntia brains were stained with $1 \mu \mathrm{g} / \mathrm{ml}$ DAPI and observed by epifluorescence microscopy.

\section{Results}

\section{Peculiarities of the Perinereis nuntia brain}

The corpora pedunculata $(\mathrm{CP})$ could easily be distinguished from other parts of the brain in DAPI stained whole mounts (Fig. 1A). The nucelei of SP were stained intensely with DAPI. $\mathrm{CP}$ are located at the latero-anterior regions of the brain and were much brighter than other parts of the brain. CP neurons were smaller, compacted and folded regularly and showed a distinct overall shape of the CP (Fig. 2B). Neurons of the $\mathrm{CP}$ contained numerous mitochondria and few neurosecretory granules. The inclusion of $\mathrm{CP}$ cells were also different from those in other parts of the brain. The nerve fibres coming from the posterior neurons, (may also belong to the $\mathrm{CP}$ itself), are leading to the center of the CP to form the CP stalk. When the nerve fibres reached out of the brain, they formed circum-oesophageal nerve rings.
In Perinereis nuntia, the CP is located at the lateral-anterior regions of the brain and can easily be differentiated from other parts of the brain by DAPI staining. CP neurons are compact and folded (Fig. 3) while the nerve fibers from the posterior neurons run through the center of the CP to form the CP stalk. From the stalk, the nerve fibers enter the brain to form the circumoesophageal nerve ring.

The corpora pedunculata show a concave bilayered primary calyx and exhibit a special central zone. Globuli cell axons occur within both layers. The bulbous accessory calyx is unlayered and sends anterior extensions beneath the primary calyx. The main input tracts into primary and accessory calyx, are the tractus olfactorio-globularis and tritocerebral tract, respectively. The pedunculus consists of one barrel with three major fiber columns, of which two originate in the primary calyx and one in the accessory calyx. Its fibers display a coaxial arrangement, superimposed on the tripartite organization.

Most of the CP cells were similar in size, and approximately $3 \mu \mathrm{m}$ in diameter. Neurons in other parts of the brain had diverse sizes of the nuclei (Fig. 1C).

The inclusion bodies of the $\mathrm{CP}$ neurons were also different from the neurons at the posterior region. The $\mathrm{CP}$ nerve cells contained little cyto-

Fig. 2. A - confocal microscopic image of a Perinereis nuntia brain whole mount stained with MIP antibody. Arrows point at immunoreactive cells and fibers at the posterior region of the brain $(\mathrm{scale}=100 \mu \mathrm{m}) ; \mathrm{B}-$ confocal microscopic image of a Perinereis nuntia whole mount brain stained with MIP antibody. Arrows point at immunoreactive cells and fibers at the posterior region of the brain $($ scale $=50 \mu \mathrm{m}) ; \mathrm{C}$ - confocal microscopic image of a $P$. nuntia whole mount brain incubated with normal rabbit serum as a control. No immunoreactivity was seen $($ scale $=100 \mu \mathrm{m})$; D epifluorescent microscopic image of paraffin sections of a Perinereis nuntia brain. Arrows point at the immunoreactive cells at the posterior region of the brain $(\mathrm{scale}=20 \mu \mathrm{m})$; E - TEM micrograph of gold-localization $(5 \mathrm{~nm})$ of MIP-like peptides on neurosecretory granules (arrow) in the nerve terminals: $\mathrm{S}$ - synaptic vesicles, $\mathrm{G}$ - neurosecretory granules $($ scale $=500 \mathrm{~nm})$.

Рис. 2. А - конфокальное микроскопическое изображение целого препарата мозга Perinereis nuntia окрашенного антителами MIP. Стрелки указывают на иммуночувствительные клетки и волокна задней области мозга (масштаб 100 мкм); В — конфокальное микроскопическое изображение целого препарата мозга Perinereis nuntia окрашенного антителами МІР. Стрелки указывают на иммуночувствительные клетки и волокна задней области мозга (масштаб 50 мкм); С - конфокальное микроскопическое изображение целого препарата мозга $P$. nuntia инкубированного с обычной сывороткой крысы в качестве контроля. Иммуночувствительность не выявляется (масштаб 100 мкм); D - эпифлуоресцентное микроскопическое изображение парафиновых срезов мозга $P$. nuntia. Стрелки указывают на иммуночувствительные клетки задней области мозга (масштаб 20 мкм); Е трансмиссионная электронная микрофотография распределения золота (5 нм) МІР-подобных пептидов на нейросекреторных гранулах (стрелка) в нервных окончаниях: $\mathrm{S}$ - синаптические везикулы, $\mathrm{G}$ - нейросекреторные гранулы (масштаб 500 нм). 

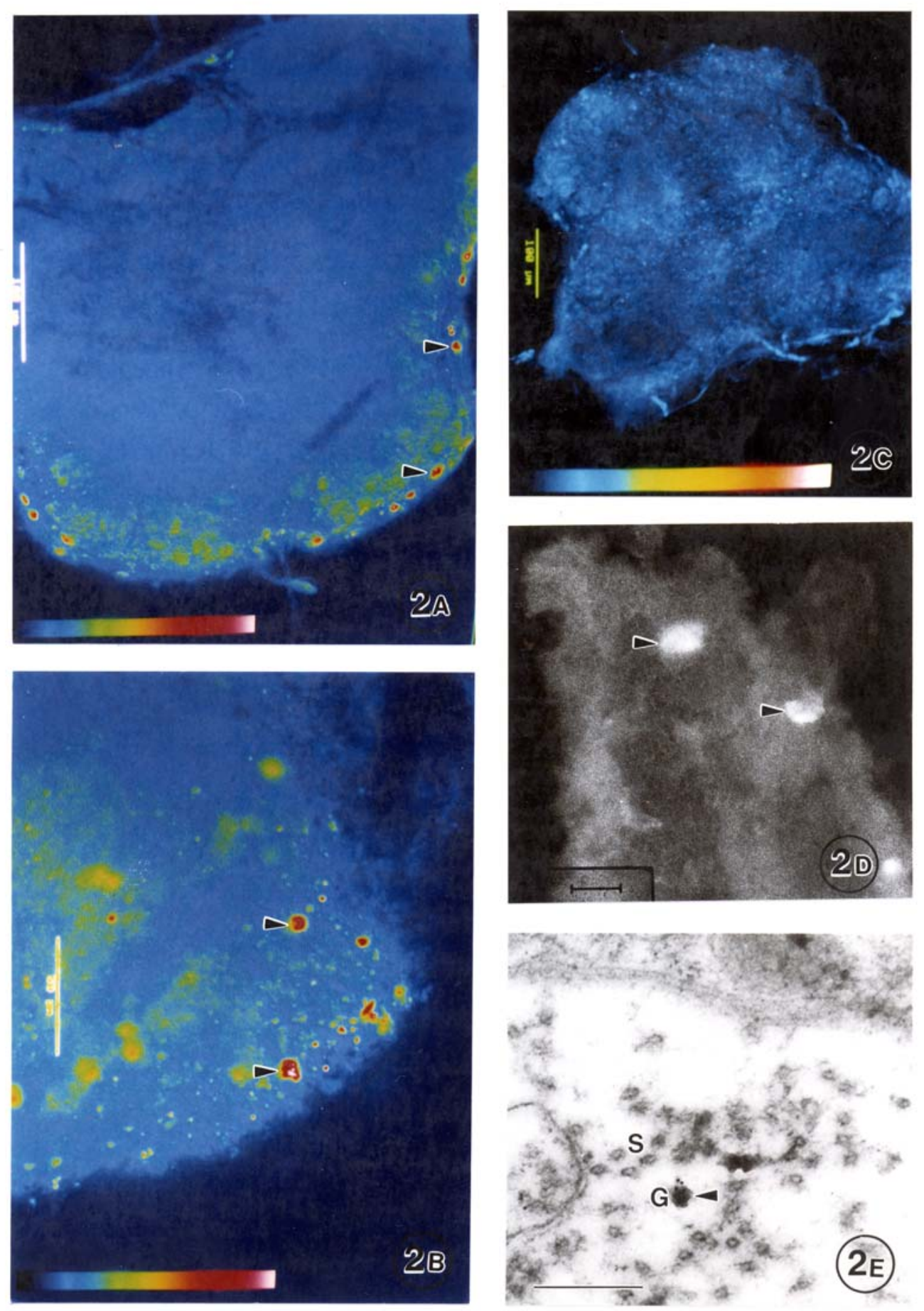


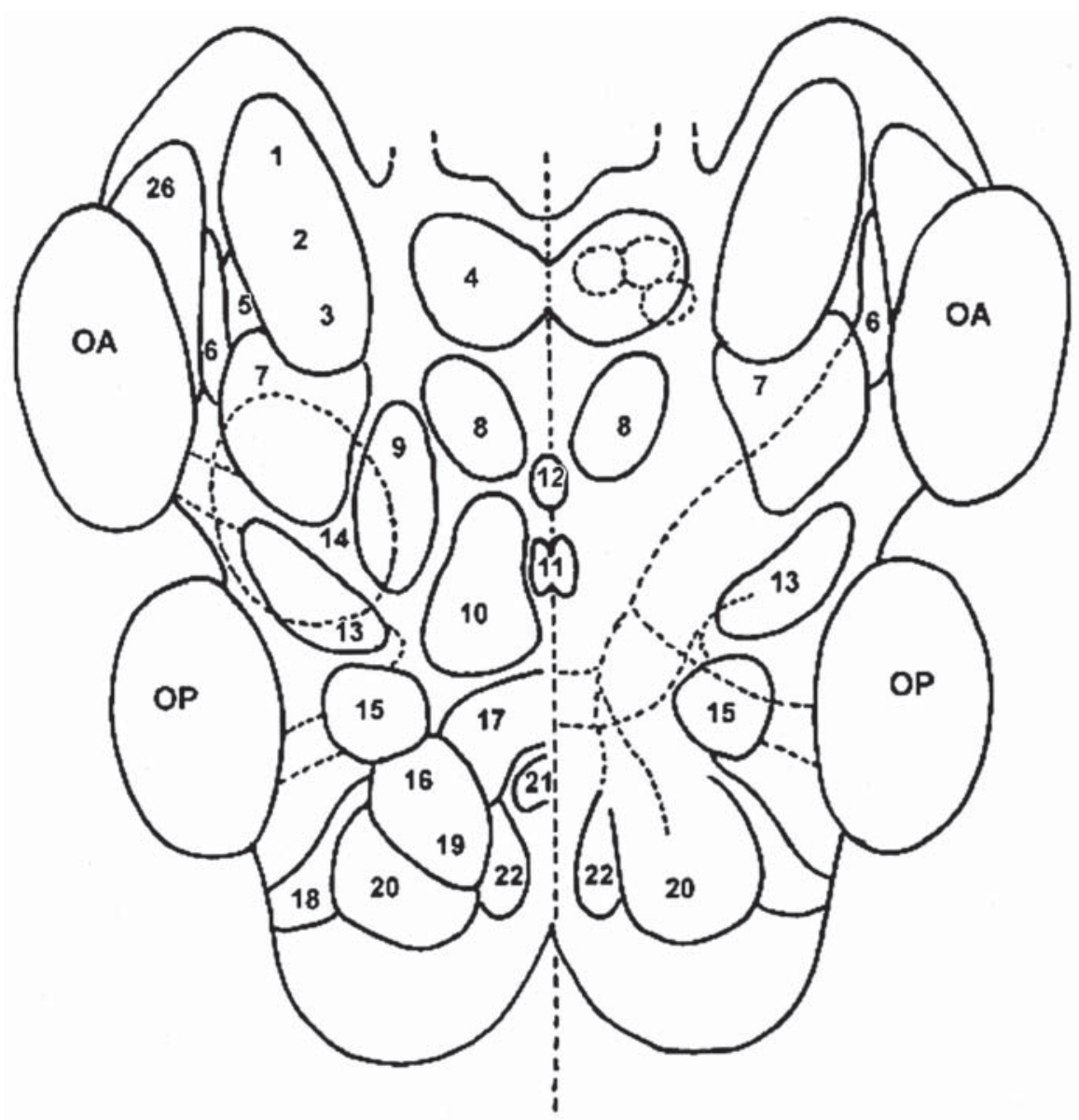

Fig. 3. Horizontal diagramatic representation of distribution of ganglionic nuclei (1-26) in the brain of Nereis diversicolor (changed after Engelhardt et al., 1982).

Рис. 3. Схематическое изображение распределения ганглиозных ядер (1-26) мозга Nereis diversicolor (по: Engelhardt et al., 1982, с изменениями).

plasm and very few secretory granules but many mitochondria (Fig. 1D, E). Most neurons in the posterior brain region, however, had a large amount of cytoplasm, varying sized secretory granules, but few mitochondria (Fig. 1F).

\section{Immunocytochemistry}

Under the confocal microscope, MIP immunoreactive perikaryas from whole mount brains were detected both in the posterior brain and in the periphery but not in the anterior $\mathrm{CP}$ region. Neurons near the surface of the brain showed strong MIP immunoreactions (Fig. 2A, B). The antibody penetrated only partially into the whole mounts. This demonstrates that immunoreactive cells are located in the periphery. Some immunoreactive nerve fibers near the neurons were also detected (Fig. 3A). The control did not show any immunoreaction (Fig. 2C). According to a diagram of the brain by Engelhardt et al. (1982 - see Fig. 1), these MIP-immunoreactive neurons (in Fig. 2A, B) belong to nuclei $13,14,15,16,18,19$, and 22 .

MIP-immunoreactive neurons were also detected in paraffin sections. These immunoreactive neurons were $10 \mu \mathrm{m}$ to $20 \mu \mathrm{m}$ in diameter (Fig. 2D) and located only in the posterior region of the brain. 
MIP-immunoreactive granules were detected in ultra-thin sections (Fig. 2E). Two kinds of secretory granules were found to be present in the same neurons: synaptic vesicles having an electron-lucent center and the neurosecretory granules having an electron-dense center. Gold particles were located only in the electron-dense granules.

\section{Discussion}

Immunoreactivity to neuropeptides is known from vertebrate and invertebrate cells located in the periphery and in the posterior part of the brain but not in the corpora pedunculata. The structure of the corpora pecunculata (CP mushroom bodies) in $P$. nuntia are similar to those described for Orthoptera (Insecta) according to Weiss (1981). Here, the CP of the progenitors of the Orthoptera are claimed to include two mutual equivalents, belayered calyces and a «double-barreled» pedunculus. In polychaetes almost all ganglionic nuclei contain a significant number of cell bodies with proteinaceous secretory material in the brain and in the ventral nerve cord (Dhainaut-Courtois et al., 1985, 1986). The wide immunohistochemical distribution of CCK-like substances in the brain, the ventral nerve cord, and the suboesophageal ganglion of Nereis strongly supports the existence of peptidergic neurons in the nervous system of polychaete annelids (Engelhardt et al., 1982). CCK-like peptides are only found within the brain nuclei according to Engelhardt et al. (1982) but not within the corpora pedunculata. Nereidine, CCK/gastrin, dynorphin, leu-enk, molluscan sodium influx stimulating peptide (SISP), FMRFamide and MSH were detected before in nucleus 20 at the posterior part of polychaete brains (see Fig. 3 Engelhardt et al., 1982; Dhainaut-Coutois et al., 1985; Dhainaut-Coutois et al., 1986; DhainautCourtois, Golding, 1988; Guissi-Kadri et al,. 1991; Dugimont et al., 1992; Krajniak, Greenberg, 1992), while the corpora pedunculata showed only choline acetyltransferase (CAT) activity (Marsden et al., 1981). There is little doubt that the corpora pedunculata and their fibres provide higher association centers and connections with palpal, optic, antennal, and nuchal centers (Golding 1992). The corpora pedunculata $(\mathrm{CP})$ of the $P$. nuntia brain can be easily distinguished from other parts of the brain. CP neurons are smaller and compacted in a regular pattern. The nuclei of $\mathrm{CP}$ were stained intensely with DAPI. The inclusion of CP cells were also different from those in other parts of the brain. Neurons of the CP contained numerous mitochondria and few neurosecretory granules.

Cells of the CP contain little cytoplasm, very few secretory granules and many mitochondria, whereas most neurons in the posterior region contain a large amount of cytoplasm and varying sized secretory granules. These morphological differences indicate that the $\mathrm{CP}$ have a different function than neuronal secretory cells in the brain. This has been indicated before by Engelhardt et al. (1982). We hypothesize that the $\mathrm{CP}$ present an important integrating center of the brain and between the brain and the suboesophageal ganglion, while the posterior part and the peripheral regions of the brain are physiological regulatory centers.

Our Figure 2 shows antibody staining only in the periphery of the brain. This indicates that immunoreactive cells are located in the periphery only. In our experiments, MIP immunoreactive cells were detected in nuclei that are important for regeneration (nuclei 13, 14, 15, 20, 22) (see Fig. 3) - whereas the cells of nucleus 17 react to amputation (see Herlant-Meewis, Van Damme, 1962). Changes of MIP staining intensity in nuclei 4, 13 and 20 were also observed. Clark and Bonney (1960) examined the brain of regenerating Nereis diversicolor and found significant increases in the quantity of stainable material in nuclei 5 and 6 after six hours. A significant increase in the volume of nucleus 4 was found $12 \mathrm{~h}$ after the loss of posterior segments. Hauenschild and Fischer (1962) stated that «the most stainable neurosecretory cells were observed in a regenerating specimen». The function of immunoreactive cells in nuclei 13, $14,15,16,18,19$, and 22 of the $P$. nuntia brain remains unclear. It also remains open whether the antibody is to be expected to cross react 
with one, a few or all isoforms of MIP in a particular species such as $P$. nuntia. As experience shows is the use of polychaete antibodies in cross-species experiments limited (Rusakov et al., 2003).

Insulin immunoreactive peptides have also been detected in invertebrates by using immunocytochemical methods, i.e. polychaetes (Porchet, Dhainaut-Courtois, 1988), other mollusks (Vanminnen, Schallig, 1990; Gomot et al., 1992; Khan et al., 1992; Sonetti et al., 1992; Kerschbaum et al., 1993), sea urchins (DePablo et al., 1988) and ascidians (O’Neil et al., 1986). Insulin is reported to induce supernumerary structures in Nereis pelagica (Boilly-Marer, 1983). The relationship between insulin-immunoreactivity and MIP-immunoreactivity is unclear, but it is shown that insulin superfamilies are present in polychaetes as well (Porchet, Dhainaut-Courtois, 1988). However, MIP peptides have not been cloned in P. nuntia. This approach and particularly real-time PCR (=RT-PCR) and insitu hybridization would be promissing approaches to confirm the expression of MIP genes in $P$. nuntia. In this study gold particles were located only in otherwise electrondense granules. This indicates that MIP-immunoreactive granules were secreted by neurons.

Our immunoreactive study is the first to demonstrate that MIP-like peptides and MIPimmunoreactive fibers exist in marine polychaetes. These results provide evidence to support the hypothesis that MIPs are peptides that are not restricted to molluses and should be found in other invertebrate taxa as well. MIPs are hormones with possible functions in growth, development, and energy metabolism (Oehlmann, Schulte-Oehlmann, 2003). There is evidence that they are involved in the control of growth and differentiation of peripheral organs and the central nervous system (CNS) (Joosse, 1988; Kits et al., 1990; Kerschbaum et al., 1993). The potential function of these peptides on nereid growth or regeneration is worth being further investigated.

Structural evolution of insulin-related peptides at the gene level has otherwise received considerable attention (Smit et al., 1993). In vertebrates, more than 50 insulin derivatives and insulin-related peptides, i.e. relaxins and insulin-like growth factors (IGFs)-I \& -II, have been structurally identified over the last two decades (Froesch et al., 1985; Girbau et al., 1987). Structural data are available for insulinrelated peptides in invertebrates, i.e. bombyxins in the lepidopteran Bombyx mori (Kawakami et al., 1989); locust insulin-related peptides (MIPs) I, II, III \& V in the freshwater snail, Lymnaea stagnalis (Smit et al., 1988, 1991; Li, Geraerts, 1992; Smit et al., 1992). In general, the gene structure of insulin-related peptides is conservative. There are extensive homologies between invertebrates and vertebrates. Structural investigations of polychaete insulin-like peptide(s) and their gene(s) could contribute to a general understanding of the evolution of insulin in the animal kingdom. Cloning of the MIP family in $P$. nuntia by real-time PCR or in situ hybridization would provide adequate tools for future confirmation of MIP gene expression in P. nuntia.

\section{Acknowledgements}

The authors thank Professor A.B. Smit at the Vrije University Netherlands (Amsterdam) for the kind supply of the MIP-antibody. We also like to acknowledge Dan Rittschof, Louis Gosselin, Steven Chiu, Kim Li, and Frank Wong for their discussion and comments on the manuscript. This work was supported in part by the following projects: National Basic Research Program of China (973 Program) (Grant \# 2007CB948104) and National Natural Science Foundation of China (\#\# 40776079 and 30671606).

\section{References}

Boilly-Marer Y. 1983. Culture de segments et induction de morphogenèses surnuméraires en presence d'insuline chez Nereis pelagica Linné (Néréidien à épitoquie, Annélide polychète)// C.R. Acad. Sci. Paris. Vol.297. P. $213-218$

Chang N.-S., Sang-Won K., Han J.-M., Lee K.-J., Hwang S.-J. 2000. Immunohistochemical studies on the visceral ganglion and right parietal ganglion of the African giant snail, Achatina fulica // Korean J. Malacology Vol.16. No.1-2. P.1-9. 
Clark R.B. 1958. The micromorphology of the supraoesophageal ganglion of Nephtys // Zool. Jahrb. Physiol. Vol.68. P.261-296.

Clark R.B., Bonney D. 1960. Influence of the supraoesophageal ganglion on posterior regeneration in Nereis diversicolor // J. Embryol. Exp. Morphol. Vol.8. P.112-118.

De Pablo F., Chamber S.A., Ota A. 1988. Insulin-related molecules and insulin effects in the sea urchin embryo // Develop. Biol. Vol.130. P.304-310.

Dhainaut-Courtois N., Golding D.W. 1988. Nervous system // W. Westheide \& C.O. Hermans (eds.). The ultrastructure of Polychaeta. P.89-120.

Dhainaut-Courtois N., Dubois M.-P., Tramu G., Masson M. 1985. Occurrence and coexistence in Nereis diversicolor O.F. Mueller (Annelida, Polychaeta) of substances immunologically related to vertebrate neuropeptides // Cell Tissue Res. Vol.242. P.97108.

Dhainaut-Courtois N., Tramu G., Beauvillain J.C., Masson M. 1986. A qualitative approach to the Nereis neuropeptides by use of antibodies to several vertebrate peptides // Neurochem. Int. Vol.8. P.327-338.

Dugimout T., Dhainaut-Courtois N., van Minnen J., de With N.D., Curgy J.-J. 1992. Some polypeptides in the nervous system of the marine worm, Nereis diversicolor, are related to the sodium influx stimulating peptide of the pulmonate freshwater snail, Lymnaea stagnalis // Gen. Comp. Endocrinol. Vol.887. P.120 126.

Engelhardt R.P., Dhainaut-Courtois N., Tramu G. 1982. Immunohistochemical demonstration of a CCK-like peptide in the nervous system of a marine worm, Nereis diversicolor O.F. Mueller // Cell Tissue Res. Vol.227. P.401-411.

Froesch E.R., Schmidt C., Schwarder J., Zapf J. 1985. Actions of insulin-like growth factors // Annu Rev. Physiol. Vol.47. P.443-367.

Girbau M., Gomez J.A., Lesniak M.A., de Pablo F. 1987. Insulin and insulin-like growth factor I both stimulate metabolism, growth and differentiation in the postneurula chick embryo // Endocrinol. Vol.121. P.14771482.

Golding D.W. 1992. Polychaeta: Nervous system // F.W. Harrison, S.L. Gardiner (eds.). Microscopic Anatomy of Invertebrates. Vol.7. Annelida. P.153-179.

Gomot A., Gomot L., Marchand C.R., Colard C., Bride J. 1992. Immunocyto-chemical localization of insulinrelated peptide(s) in the central nervous system of the snail Helix aspersa Mueller: Involvement in growth control // Cell Mol. Neurobiol. Vol.12. P.21-32.

Guissi-Kadri S., Dhainaut-Courtois N., Porchet M., Curgy J.-J. 1991. Precursors of neuropeptides in the marine worm Nereis diversicolor. In vitro translation of a precursor related to human prepro-cholecystokinin and immunolocalization of this precursor in the nervous system // Biol. Cell Vol.71. P.81-87.

Hauenschild C.D., Fischer A. 1962. Neurosecretory control of development in Platynereis dumerilii // Mem. Soc. Endocrinol. Vol.12. P.297-312.
Herlant-Meewis H., van Damme N. 1962. Neurosecretion and wound healing in Nereis diversicolor // Mem. Soc. Endocrinol. Vol.12. P.287-296.

Joosse J. 1988. The hormones of mollusks // H. Laufer, R.G.H. Downer (eds.). Endocrinology of selected invertebrate types. New York: Liss. P.89-140.

Kawakami A., Iwami M., Nagasawa H., Suzuki A., Ishizaki H. 1989. Structure and organization of four clustered genes that encode bombyxin, an insulin-related brain secretory peptide of the silkmoth Bombyx mori // Proc. Natl. Acad. Sci. (USA) Vol.84. P.6843-6847.

Kerschbaum H.H., Holzinger K., Hermann A. 1993. Endocrine-like cells and insulin-binding sites in the epineurium of Helix pomatia // Tissue Cell Vol.25. P.237243.

Khan H.R., Griffond B., Saleudin A.S.M. 1992. Insulinlike peptide(s) in the central nervous system of the snail Helisoma duryi // Brain Res. Vol.580. P.111114.

Kits K.S., de Vries N.J., Ebberink R.H.M. 1990. Molluscan insulin-related neuropeptide promotes outgrowth of dissociated neuron cultures // Neurosci. Lett. Vol.109. P.253-258.

Krajniak K.G., Greenberg M.J. 1992. The localization of FMRFamide in the nervous and somatic tissues of Nereis virens and its effects upon the isolated esophagus // Comp. Biochem. Physiol. Vol.101C. P.93100.

Krajniak K.G., Price D.A. 1990. Authentic FMRFamide is present in the polychaete Nereis virens // Peptides. Vol.11. P.75-77.

Laqueux M., Lwoff L., Meister M., Goltzene F., Hoffmann J. 1990. cDNAs from neurosecretory cells of brains of $B$ (Insecta, Orthoptera) encoding a novel member of the superfamily of insulins // Europ. J. Biochem. Vol.187. P.249-254.

Li K.W., Geraerts W.P.M. 1992. Isolation and chemical characterization of a novel insulin-related neuropeptide from the freshwater snail, Lymnaea stagnalis // Europ. J. Biochem. Vol.205. P.675-678.

Li K.W., Geraerts W.P.M., Joosse J. 1992. Purification and sequencing of molluscan insulin-related peptide II from the neuroendocrine light green cells in Lymnaea stagnalis // Endocrinology. Vol.130. P.34273432.

Marsden J.R., Bsata N., Cain H. 1981. Evidence for a cerebral cholinergic system and suggested pharmacological pattern of neural organization in the prostomium of the polychaeta Nereis virens (Sars) // Tissue Cell. Vol.13. P.255-267.

Oehlmann J., Schulte-Oehlmann U. 2003. Endocrine disruption in invertebrates // Pure Appl. Chem. Vol.75. No.11-12. P.2207-2218.

O’Neil G.S., Falkner S., Thorndyke M.C. 1986. Insulin-like immunoreactivity in the neural ganglion of the ascidian Ciona intestinalis // Acta Zool. Vol.67. P.147-153.

Porchet M., Dhainaut-Courtois N. 1988. Neuropeptides and monoamines in annelids // M.C. Thorndyke, G.J. Goldsworthy (eds.). Neurohormones in invertebrates. Cambridge University Press. P.219-234. 
Rusakov Y.I., Kolychev A.P., Shapilov V.N., Bondareva V.M. 2003. Insulin-like peptides of the cerebropleural ganglion of the mollusk Anodonta cygnea: isolation, purification, and radioligand analysis // J. Evol. Biochem. Physiol. Vol.39. No.4. P.4.

Schwartz J.H. 2001. Neurotransmitters // Encyclopedia of life sciences. Nature Publishing Group (www.els.net). P.1-9.

Smit A.B., Vreugdenhil E., Ebberink R.H.M., Geraerts W.P.M., Klootwijk J., Joosse J. 1988. Growth-controlling molluscan neurons produce the precursor of an insulin-related peptide // Nature. Vol.331. P.535538 .

Smit A.B., Geraerts W.P.M., Meester I., van Heerikhuizen H., Joosse J. 1991. Characterization of a cDNA clone encoding molluscan insulin-related peptide II of Lymnaea stagnalis // Europ. J. Biochem. Vol.199. P.699-703.

Smit A.B., Thijsen S.F.R., Geraerts W.P.M., Meester I., van Heerikhuizen H., Joosse J. 1992. Characterization of a cDNA clone encoding molluscan insulin-related peptide V of Lymnaea stagnalis // Mol. Brain Res. Vol.14. P.7-12.
Smit A.B., van Marle A., van Elk R., Bogerd J., van Heerikhuizen H., Geraerts W.P.M. 1993. Evolutionary conservation of the insulin gene encoding molluscan insulin related peptide III from Lymnaea stagnalis // J. Mol. Endocrinol. Vol.11. P.103-113.

Smit A.B., Kesteren R.E.V., Li K.W., Minnen J.V., Spijker S., Heerikhuizen H.V., Geraerts W.P.M. 1998. Towards understanding the role of insulin in the brain: lessons from insulin-related signaling systems in the invertebrate brain // Prog. Neurobiol. Vol.54. P.35-54.

Sonetti D., van-Heumen W.R.A., Roubos E.W. 1992. Light- and electronmicroscopic immunocytochemistry of a molluscan insulin-related peptide in the central nervous system of Planorbarius corneus // Cell Tissue Res. Vol.267. P.473-481.

Vanminnen J., Schallig H.D.F.H. 1990. Demonstration of insulin-related substances in the central nervous system of pulmonates and Aplysia californica // Cell Tissue Res. Vol.260. P.381-386.

Weiss M.J. 1981. Structural patterns in the corpora pedunculata of Orthoptera: a reduced silver analysis // J Comp. Neurol. Vol.203. No.3. P.515-553. 